The Journal of Animal \& Plant Sciences, 30(3): 2020, Page: 634-641

ISSN (print): 1018-7081; ISSN (online): 2309-8694

\title{
EXAMINATION OF FERTILITY INDICATORS OF EUROPEAN BROWN HARES (Lepus europaeus) IN EASTERN HUNGARY
}

\author{
P. Farkas ${ }^{*}$, Sz. Kusza ${ }^{2}$, P. Balogh ${ }^{3}$ and I. Majzinger ${ }^{4}$ \\ ${ }^{1,2}$ Institute of Animal Science, Biotechnology and Nature Conservation, Faculty of the Agricultural and Food Sciences \\ and Environmental Management, Doctoral School of Animal Science, University of Debrecen, Debrecen, Hungary, \\ ${ }^{3}$ Department of Research Methodology and Statistics, Faculty of Economics and Business Institute of Sectoral \\ Economics and Methodology, University of Debrecen, Debrecen, Hungary, \\ ${ }^{4}$ Institute of Animal Sciences and Wildlife Management, Faculty of Agriculture, University of Szeged, \\ Hódmezővásárhely, Hungary \\ Corresponding Author’s email: farkas.fajsz@gmail.com
}

\begin{abstract}
A decreasing tendency in the populations of the European brown hare can be observed in the whole of Europe from the mid-1960s to the present day. Among the reasons for declining populations fertility indicators of females are also mentioned. The aim of our study was to determine the reproductive parameters of the species in eastern Hungary. During the years 2015-2016, we studied two hundred animals (1219, 79 ${ }^{\AA}$ ). Altogether, 121 uteri (81 adult and 40 juvenile) and 79 testicles were examined. The number of placental scars showed us the number of offspring in reproductive periods. The age of hares was estimated based on the weight of dried eye lens. The number of placental scars in the general linear model was significantly affected by hunting areas, the age of animals, the interaction of the former two, and also by body weight and kidney fat indices. The age of hares, the hunting year, the effect of the interaction of the former two, and body weight seriously contributed to the weight of the testicles. Based on the number of placental scars, $70.37 \%$ of adult and $62.50 \%$ of juvenile females were proved to be capable of reproduction. One can conclude from the above that although fertility indicators may play an important role in the decreasing trend in the numbers of Hungarian brown hare populations, they are definitely not the main causes.
\end{abstract}

Keywords: Brown hare, fertility, placental scars

https://doi.org/10.36899/JAPS.2020.3.0075

Published online March 25, 2020

\section{INTRODUCTION}

The drop concerning the populations of the European brown hare (Lepus europaeus Pallas, 1778.) population can be observed across Europe (Smith et al., 2005) -including Hungary- from the sixties until now (Csányi, 2016). According to some authors, the possible reasons for this are habitat reduction, intensive agriculture (Beuković et al., 2011), the excessive use of herbicides (Beuković et al., 2017, Beuković et al., 2018, Mezei et al., 2018) and weather factors (Beuković et al., 2013). Other authors mention the effects of diseases and parasites (Möller, 1980), the increasing number of predators (Reynolds et al., 2010), traffic accidents (Roedenbeck and Voser, 2008). Fertility indicators such as fecundity, pregnancy rate, conception rate, reproductive success of females play a key role in population dynamics of small game (Kovács and Heltay, 1993). Fertility indicators can be defined in many ways. Fecundity shows the potential number of female offsprings by each female (Caughley and Sinclair, 1994) or from a different approach, the potential number of all offsprings by each female (Chapman, 1974). Pregnancy rate is the proportion of fertile females to all females.
Conception rate indicates the number of offsprings delivered by each female in one reproductive period, whereas reproductive success means the number of offsprings raised by each female in the aforementioned period.

Concerning the fertility rates of the European brown hare, only old data and data consisting little number of samples are available in Hungary. (Kovács and Heltay, 1993; Gál, 2006). The ratio of reproductive females and the number of placental scars by each female are of great significance in the reproductive parameters of the species. First and last the aim of our study was to examine the reproductive performance of the European brown hare in two different hunting areas, where the species can be found in relatively high abundance.

Reproductive characteristics: Young brown hares are sexually mature at the age of six-seven months (Broekhuizen and Maaskamp, 1981), but some individuals may be sexually mature at the age of three months (Gál, 2006). The reproductive cycle of brown hares is determined by photoperiodism which falls between February and November (Faragó, 2002). In the Mediterranean areas the species is capable of reproduction all year round (Antoniou et al., 2008). In 
Greece, the ratio of pregnant hares was $18 \%$ in October and $45 \%$ in January. In Poland, the relatively long reproductive period (from January till August) was described as well (Kozdrowski et al., 2011). Females become sexually more active with the increase of daylight length, due to decreasing melatonin levels. Ovulation is induced by mating (Kovács and Heltay, 1993). Normally, the gestation period of the brown hare is 41 days but it is capable of getting pregnant every 38 days due to a phenomenon called superfetation. Between the $34^{\text {th }}$ and $40^{\text {th }}$ days of pregnancy, repeated copulation is common, peaking on the $37-38^{\text {th }}$ days (Martinet, 1980). Sometimes, extra-uterine pregnancy also occurs (Gál, 2006). The number of placental scars on the uterus equals the number of hares born in the given reproductive period (Bray et al., 2003). Placental scars remain visible for several months (Kovács and Heltay, 1993; Gál and Marosán, 2002). There is a statistical relationship between the number of placental scars and the weight of female brown hares (Beuković et al., 2013). The mortality rate of the r-strategist brown hare is high. From spring to autumn, the mortality rate of adult hares is lower than that of young ones. In populations where the proportion of reproduction is low, the mortality of adult hares is low too (Kovács and Heltay, 1993). The mortality rate of young hares was higher than intrauterine loss and can be different in neighboring hunting areas (Faragó, 2002).

Concerning reproduction, male hares in Hungary become more active between December and September, while females between January and October. Testicles weigh more than 10 grams in the reproductive period and about 1 gram in non-breeding period (Széky, 1973). Any bacterial infection may also increase the weight of testicles (Vetési, 1990). Cadmium in the testicles can lead to the reduction of the diameter of lumen (Van Tu and Sas, 1989).

\section{MATERIAL AND METHODS}

The project is co-financed by the European Union and the European Social Fund. The publication is supported by the EFOP-3.6.3-VEKOP-16-2017-00008 project.

Study areas: Places of origin of samples were from Túrkeve (47 $7^{\circ} 9^{\prime \prime} \mathrm{N}$ and $20^{\circ} 49^{\prime} 15.5^{\prime \prime}$ E) in JászNagykun-Szolnok county and from Békéscsaba $\left(46^{\circ} 43^{\prime}\right.$ $49.5^{\prime \prime} \mathrm{N}$ and $20^{\circ} 56^{\prime} 12^{\prime \prime} \mathrm{E}$ ) in Békés county (Fig. 1.)

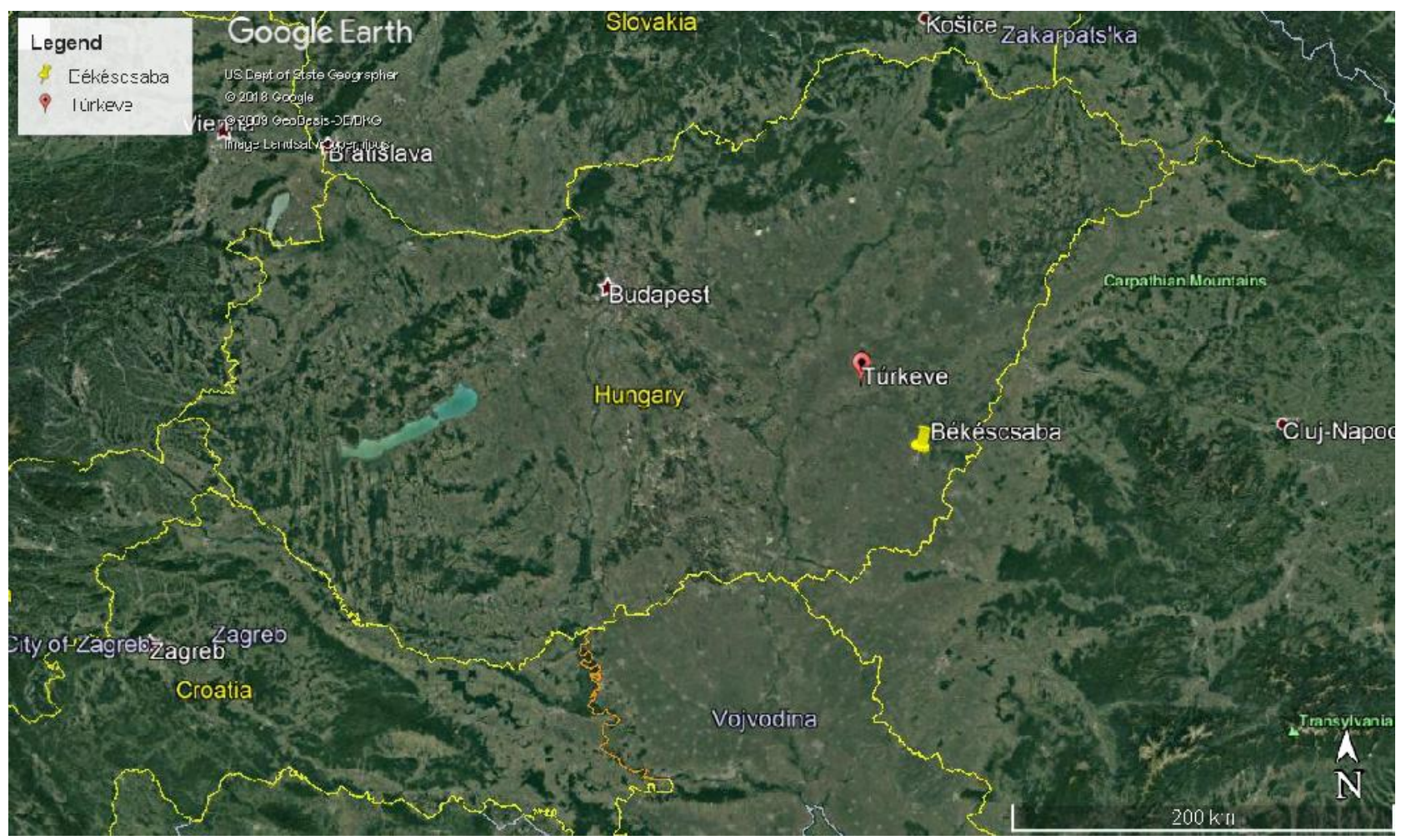

Fig. 1.Places of origin of samples.

Most parts of the two areas (and of the hunting areas too) are under agricultural cultivation. The first examined area (around Túrkeve) is located 83 meters above sea level, on the borders of two national parks. The most common vegetation in the area in the test period were stoop crops $(27 \%)$, meadows $(15 \%)$, alfalfa $(13 \%)$ 
and wasteland (7\%) (Fig 2. a). Its total area is more than 20.000 hectares. The second examined area (around Békéscsaba) has 4.700 hectares of land and is located 89 meters above sea level. It is just outside the chief town of the county close to two main roads. In the hunting area the typical agricultural plants are the following: stoop crops (46\%), grain (31\%) alfalfa (12\%) (Fig. 2 b.).
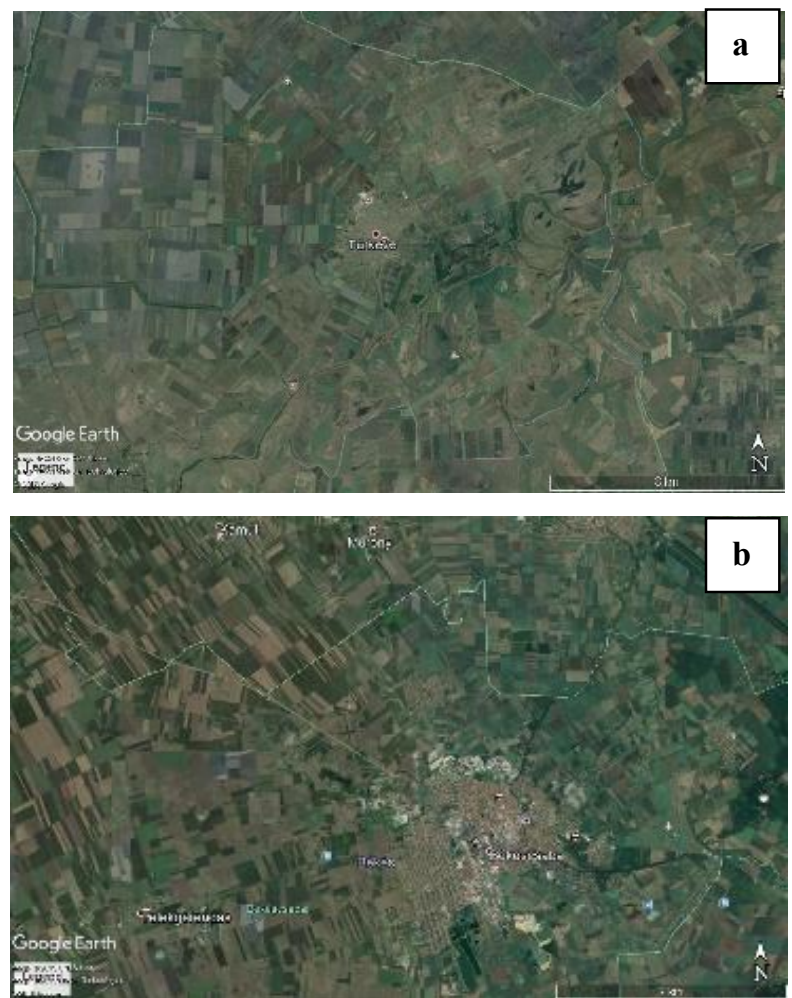

Fig. 2. Habitat structure in Túrkeve (a) and in Békéscsaba (b).

Sampling: In each hunting area the following data were calculated: population density, ratio of young hares in the autumn population, sex ratio, fertility rate of females, average yearly progeny per mother, number of occurrent pathological lesions.

We estimated population density by area every November and February at night with spotlight counting method (Kovács, 1986 and Zellweger-Fischer et al., 2011) travelling on board a jeep (at 5-6 mph). Precipitation -free days were chosen for the estimation process. Estimations were carried out on about $10 \%$ of the hunting fields on two successive days, in areas where little plant cover could be found, close to nutrition-areas. Population density (animals/hectares) was calculated by year and by season based on the average number of hares in the sampling areas, using the following formula:

Population density $=\mathrm{n} / \mathrm{t}$

$\mathrm{n}=$ average number of hares in sample area, $\mathrm{t}=$ size of sample area $+/-10 \%$ correction.

Population density was satisfactory in both areas in November (2015), with a value of 0.15 animal/hectares in the first study area (Túrkeve) and 0.11 in the second study area (Békéscsaba) $(\alpha=0.05)$. In February (2016) it was 0.12 in the first area and 0.09 in the second area. In autumn 2016 these values were 0.13 (in the first area) and 0.10 in the second one, respectively.

The organ samples $(n=200)$ were collected in the hunting period of 2015-2016, from $1^{\text {st }}$ of October until $31^{\text {st }}$ of December (the number of our samples made up about $25-30 \%$ of allowed shootable hares) (Table 1). Hares were weighed and their sexes were determined immediately after the hunting had finished. Talking about the ages of samples in the hunting bag, there were 25 juveniles and 24 adults $(n=49)$ in the first field and 31 juvenile and 38 adult hares $(n=69)$ in the second study area in 2015. In 2016 there were 13 juveniles and 26 adults $(n=39)$ in the first field and 12 juvenile and 31 adult hares $(n=43)$ in the second area (Table 1$)$.

Table 1. Number of shot brown hares in hunting bags by area.

\begin{tabular}{|c|c|c|c|c|c|c|c|}
\hline \multirow[b]{2}{*}{ Year } & \multirow[b]{2}{*}{ area* $^{*}$} & \multicolumn{6}{|c|}{ number of shot brown hares } \\
\hline & & juv. & ad. & juv. +9 & fert.juv. + & ad. & fert. ad. $P$ \\
\hline \multirow{3}{*}{2015} & 1 & 25 & 24 & 8 & 4 & 20 & 14 \\
\hline & 2 & 31 & 38 & 18 & 13 & 20 & 16 \\
\hline & 1 & 13 & 26 & 6 & 3 & 20 & 12 \\
\hline 2016 & 2 & 12 & 31 & 8 & 5 & 21 & 15 \\
\hline Total & & 81 & 119 & 40 & 25 & 81 & 57 \\
\hline
\end{tabular}

*1 =Túrkeve, 2 =Békéscsaba, ad.=adult, juv=juvenil, fert.=fertile.

The examined organs were male and female genitalia, kidneys and renal fat. The latter was needed in order to estimate the physical conditions of the animals. Although the autumn period is may not be the best to assess male parameters, the December period is already suitable for it. Namely the sexual cycle of male brown hares in Hungary starts in December and, depending on the weather, ends in August or in September (Faragó, 2002). The same two hunting methods were applied in each hunting area and year: round hunting (with 25-30 
hunters, 25-30 beaters and 3-4 dogs) and search huntings (with 4 hunters, 4 beaters and 3 dogs). The samples were collected in both areas at the beginning, in the middle and at the end of the hunting season. Sampling happened randomly.

Analyses of samples: We estimated the age of hares based on the weight of dried eye lens (Kovács and Heltay, 1993). After hunting, eye lenses were taken from hares promptly. After a fixation of 24 hours in $4 \%$ of buffered formalin solution, the eye lenses were dried for 210 minutes in a thermostat (Memmert) at $103{ }^{\circ} \mathrm{C}$ in the laboratory. They were measured on a precise analytic scale (PRL-II) with a precision of one $\mathrm{mg}$. The animals were divided into two groups: dried eye lenses weight less than $280 \mathrm{mg}$ (juvenile) and heavier than $280 \mathrm{mg}$ (adult), based on (Köhalmy, 1999). All animals captured were used to estimate young ratio (r), using the formula Kovács-Heltay (1993):

$\mathrm{r}=$ number of juvenil/number of adult

For the purpose of determining the reproductive indicators of females, uteri were examined. The number of placental scars indicate previous pregnancies (Hackländer et al., 2011), so we considered all the females that had at least one placental scar fertile (Fig. 3).

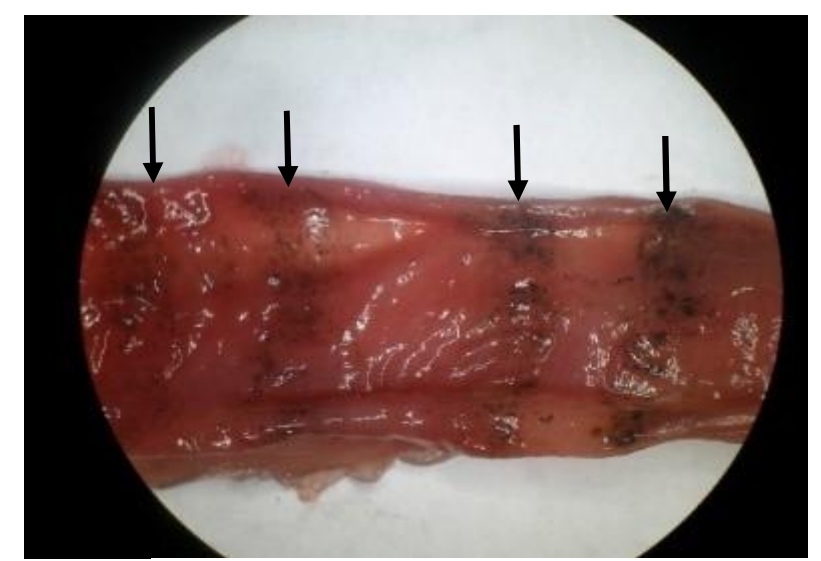

Fig. 3. Longitudinal section of the uterus with placental scars.

Shortly after the shooting of the animals, their uteri were frozen, because high water content of the tissue makes it difficult to count placental scars. The condition of animals were estimated by calculation of the kidney fat index (KFI). The KFI was calculated by the following method Caughley (1977):

$\mathrm{KFI}=$ (the weight of the kidneys + the weight of perirenal fat)/the weight of kidneys.

The following results were applied during evaluation: bad 0.000-0.600, average 0.601-1.400, good 1.401-2.000, and very good: more than 2.000 (Majzinger and Csányi, 2017).
Data analysis: Normality and homogeneity of variances were verified for all variables, and those that did not fulfil parametric test requirements were normalized or tested for positive kurtosis (Underwood, 1996). Three models of general linear model (GLM) were performed. It was compared the differences between the number of placental scars, the conditions of hares (by KFI) and weight of testicles by hunting areas, years and age of animals and its interactions. To test of equality of error variances Levene-test and to test pairwise comparisons Bonferroni test used. Each mentioned variables was included as the dependent variable, while hunting areas, years, sex and age were categorical factors. Body weight, KFI used as covariate. IBM SPSS statistics for Windows, version 22.0 (2013) software was used for the analysis. SPSS 22.0 (2013) software used for analysing the proportion of sex (1:1) and age of animals (1:1) using Chi-square Test.

\section{RESULTS AND DISSCUSION}

Age strucrures of populations by hunting bag: Talking about age structures of samples in the hunting bag, there were 25 juveniles and 24 adults $(n=49)$ in the first field and 31 juvenile and 38 adult hares $(n=69)$ in the second study area in 2015. The juvenile-adult ratio on the two territories in autumn was 0.75 and 0.5 (2015). In 2016 the hunting bag contained 13 juveniles and 26 adults $(n=39)$ $r_{3}=0.50$ in the first area and in the second one 12 juvenile and 31 adult hares $(n=43) r_{4}=0.39$. Sex ratio was significantly different from expected 1:1 (Chisquare $=8.82, \mathrm{df}=1, \mathrm{p}=0.003, \mathrm{n}=200)$ (Table 2).

Table 2. The juvenile/adult ratio and sex ratio by hunting areas.

\begin{tabular}{cccc}
\hline Year & $\begin{array}{c}\text { hunting } \\
\text { area }^{*}\end{array}$ & $\begin{array}{c}\text { r=nuber of } \\
\text { juvenile/ } \\
\text { number of adult }\end{array}$ & $\begin{array}{c}\text { sex ratio=number } \\
\text { of male/number } \\
\text { of female }\end{array}$ \\
\hline 2015 & 1 & 0.75 & 0.75 \\
2016 & 2 & 0.5 & 0.82 \\
& 1 & 0.5 & 0.5 \\
& 2 & 0.39 & 0.48 \\
\hline
\end{tabular}

*1=Túrkeve, $2=$ =Békéscsaba.

The proportion of young and adult animals was significantly different from 1:1 (Chi-square=31.688, $\mathrm{df}=1, \mathrm{p}<0.001, \mathrm{n}=200)$. The ratio of male to female animals in the year 2015 in both areas were more than in 2016 (Table 2).

Tests of placental scars: Significant differences were found between placental scars by hunting areas (GLM 1: $\left.F_{1,110}=7.549 ; p=0.007\right)$ and body weight of hares (GLM 1:

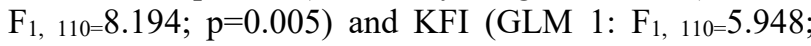
$\mathrm{p}=0.016)$ and age of hares (GLM 1: $F_{1}, 110=10.215$; 
$\mathrm{p}=0.002$ ) (Table 3). The interaction of hunting area and age of hares was significant, too (GLM 1: $F_{1,110}=7.591$; $\mathrm{p}=0.007)$. Significant differences were not found between placental scars by years (GLM 1: $F_{1,110=0.186 \text {; }}$ $\mathrm{p}=0.667)$. Such as the interactions of hunting area and year (GLM 1: $\left.F_{1,110}=1.540 ; p=0.217\right)$, age of hares and

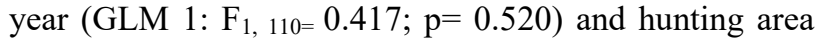
and year and age of hares (GLM 1: $F_{1}, 110=3.208 ; \mathrm{p}=$ 0.076 ). In the model adjusted $R^{2}$ was 0.357 .

Table 3. The results of different GLM models.

\begin{tabular}{|c|c|c|c|}
\hline GLM 1. & B & $F_{1,110}$ & p \\
\hline Area & 0.25 & 7.5 & 0.007 \\
\hline Year & 0.05 & 0.2 & 0.67 \\
\hline Age & 0.30 & 10.2 & 0.002 \\
\hline area*year & 0.12 & 1.5 & 0.22 \\
\hline area*age & 0.26 & 7.6 & 0.007 \\
\hline year*age & 0.06 & 0.4 & 0.52 \\
\hline area* year*age & 0.17 & 3.2 & 0.08 \\
\hline body weight & 0.26 & 8.2 & 0.005 \\
\hline KFI & 0.23 & 5.9 & 0.016 \\
\hline GLM 2. & B & $\mathbf{F}_{1,190}$ & $\mathbf{p}$ \\
\hline Area & 0.16 & 4.9 & 0.027 \\
\hline Year & 0.56 & 86.8 & $<0.001$ \\
\hline area*year & 0.05 & 0.3 & 0.59 \\
\hline body weight & 0.20 & 8.3 & 0.004 \\
\hline GLM3. & B & $F_{1,69}$ & $\mathbf{p}$ \\
\hline Area & 0.01 & 0.0 & 0.92 \\
\hline Year & 0.32 & 7.8 & 0.007 \\
\hline Age & 0.30 & 6.7 & 0.012 \\
\hline area*year & 0.07 & 0.3 & 0.57 \\
\hline area*age & 0.09 & 0.5 & 0.46 \\
\hline year*age & 0.25 & 4.4 & 0.039 \\
\hline area*year*age & 0.01 & 0.0 & 0.92 \\
\hline body weight & 0.24 & 4.3 & 0.042 \\
\hline
\end{tabular}

GLM1. Dependent Variable: number of placental scars; GLM2. Dependent Variable: Kidney Fat Index; GLM3. Dependent Variable: weight of testicles. B: Effect size.

Those females which became mature were mostly fertile. The fertility ratio in the two year average in the first study area was 0.61 and in the second hunting area it was 0.73 The reproductive performance of all females can be calculated based on the number of placental scars-(Table 4).

Table 4. The average placental scars (pieces/all female brown hares) by hunting areas.

\begin{tabular}{ccccc}
\hline Year & hunting area $^{*}$ & N & Mean & SD \\
\hline \multirow{2}{*}{2015} & 1 & 28 & 6.14 & 5.45 \\
& 2 & 38 & 7.79 & 3.63 \\
2016 & 1 & 26 & 4,68 & 3.65 \\
& 2 & 29 & 4.83 & 3.44 \\
\hline
\end{tabular}

*1=Túrkeve, $2=$ Békéscsaba.
In 2015 this value in the first area was 6.14 per hare $(\mathrm{n}=28, \mathrm{SD}=5.45)$, the range of samples was between 0 and 12 . In 2015, the average number of placental scars in the second study area was 7.79 per all female $(n=38$, $\mathrm{SD}=3.63$ ). The minimum number of placental scars was 0 and the maximum was 16 . In the given years between the placental scars by hunting areas were not significant diference. In the first study area in 2016 the reproductive performance was much lower ( 4.68 per all females $n=26$, $\mathrm{SD}=3.65$ ) than in 2015. The range of samples was between 0 and 13. In the second study area the average placental scars were much lower too, than in 2015 (4.83 per all females $\mathrm{n}=29, \mathrm{SD}=3.44$ ) (Table 4 ). In total, the mean number of placental scars of juvenile fertile hares in 2015 was $8.41(\mathrm{n}=17, \mathrm{SD}=4.32)$ and in case of adults fertile one it was $8.60(\mathrm{n}=30, \mathrm{SD}=2.47)$ (Table 4). In 2016 , the same values were $2.75(\mathrm{n}=8, \mathrm{SD}=1.67)$ in case of juveniles and 7.33 in case of adult hares $(n=27$, $\mathrm{SD}=2.45)$. Twelve $(9,91 \%)$ animals developed pathological alterations. Four cases were tumours on the inside and outside of the uterus by adult hares. Metritis and cysts were found in both age groups. We found only sign of pregnancy in two cases of 12 sick animals.

Tests of condition: In the second GLM model in which were tested the relationship between the condition (calculated by KFI) and hunting area, year and its interactions significant differences were found between KFI and hunting areas (GLM 2: $F_{1,190}=4.941 ; p=0.027$ ) and KFI and hunting years (GLM 2: $F_{1}, 190=86.848$; $\mathrm{p}<0.001$ ) (Table 3 ). The interactions of year and huting

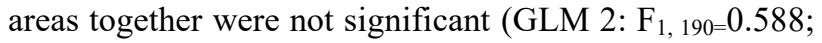
$\mathrm{p}=0.294)$. The effect of body weight on KFI was

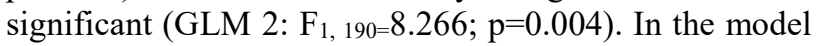
adjusted $\mathrm{R}^{2}$ was 0.378 .

Tests of weight of testicles: In the third GLM model in which were tested the weight of testicles as dependent variable there were significant differences between the body weight (GLM 3: $\mathrm{F}_{1,69}=4.302 ; \mathrm{p}=0.042$ ) and year

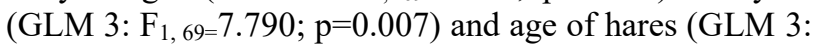
$F_{1,69}=6.715 ; p=0.012$ ) (Table 3). The effect of interaction between year and age of hares was significant, too (GLM 3: $\mathrm{F}_{1,69}=4.415 ; \mathrm{p}=0.039$ ). In the model adjusted $\mathrm{R}^{2}$ was 0.329 . By male hares between 1 of October and 31 of December, the average weight of testicles in all samples was $1.88 \mathrm{~g}(\mathrm{n}=78, \mathrm{SD}=0.91)$. The range of samples was from $1 \mathrm{~g}$ to $4 \mathrm{~g}$. The average weight in case of young animals $1.49 \mathrm{~g}(\mathrm{n}=41, \mathrm{SD}=0.59)$ and in case of adult ones $2.32(\mathrm{n}=37, \mathrm{SD}=1.01)$.

The reproductive parameters of the brown hare are essential parameters for reasonable game management. The estimated population density is correspond to data in Poland reported by Panek (2009) in both areas, but different from the information given by Pielowski and Pinkowski (1992). In the examinations of Kamieniarz et al., (2013) in Poland the estimated 
abundance of hares were 0.41-0.95 individuals/ hectares and in Germany $0.19-0.48$ in the autumn population. The abundance in our study areas $0.9-1.5$ is good in Hungary, but less than in Croatia 0.13-2.03 (Pintur et al., 2006) or in Srebia Montenegro 1.1-3.0 by data reported Šelmić (1984). From practical game management perspective the proportion of young and adult hares in autumn populations better 60:40 than 50:50 (Kovács and Heltay, 1993). In all samples were more female, than male. It is a question that it shows the real sex ratio or it demonstrates the practical experience that female hares escapes only last minute by hunting. In some studies the infertility of female can reach to $35-40 \%$ (Möller, 1980). In the examination of Bensinger et al., (2000) $84 \%$ of adult $(\mathrm{n}=$ $183)$ and only $1 \%$ of juvenile $(n=128)$ hares showed reproduction. In the research results of Kovács and Heltay (1993) less than $60 \%$ of individuals that were older than five years participated in reproduction, and less than two percent of young ones. In a seven year long research conducted by Gál (2006) in western Hungary, the proportion of adult females participating in reproduction was $64.9 \%$, whereas that of young hares was $37.5 \%$. In our study the score was similar, the fertility rate of all females was 0.71 and 0.64 in year 2015 and 2016 in relation to all hares. In some populations the proportion of abortive females streches up to $35-40 \%$ Gál (2006). The average yearly progeny of the fertile females was 8.50 (2015) and 5.04 (2016) (Table 5).

Table 5. The average placental scars (pieces/fertile brown hares) by age groups.

\begin{tabular}{cccccccc}
\hline Year & $\begin{array}{c}\text { age } \\
\text { group }\end{array}$ & N & & mean & min & max & SD \\
\hline 2015 & 1 & 17 & 8.41 & 8.5 & 2 & 12 & 4.32 \\
& 2 & 30 & 8.60 & & 1 & 16 & 2.47 \\
2016 & 1 & 8 & 2.75 & 5.04 & 1 & 13 & 1.67 \\
& 2 & 27 & 7.33 & & 2 & 13 & 2.45 \\
\hline
\end{tabular}

${ }^{*} 1=$ juvenile, $2=$ adult.

The average litter size by other authors in Hungary was from 3.72 (Faragó, 2002) to 5-7.5 (Farkas, 1983). In Denmark, this value was lower than in Central Europe, it was 1.93-2.54 offsprings per female (Hansen, 1992). The mean anual progeny of young females was 7.39 and in case of adult females it was 9.32 (Majzinger, 2013). In our present study it was 5.63 per uterus in all adult females $(n=81$, Standard deviation 2.45) and 4.13 per uterus in all young females $(n=40$, Standard deviation 4.8). In France, fertility was 12.20-15.00 posteriors per breeding female per year (Marboutin et al., 2003). In Croatia, a reproduction coefficient is used to show the survival rate of offsprings per female (Pintur et al., 2006) which is equal to the number of juvenile hares/number of adult female hares. In the examinations of Beuković et al., (2013) the reproductive potential by placental scars of brown hares, which were heavier than $4,5 \mathrm{~kg}$ were significantly better (averages 3,57 pieces/female) than in the group 4-4,5 $\mathrm{kg}$ (averages 2,07 pieces/female) or in the group under $4 \mathrm{~kg}$ (averages 1,14 pieces/female).

Pathological alterations were found by nearly every tenth female. In Hungary the following genital lesions of females are mentioned most frequently (Vetési, 1990): adenocarcinoma of the uterus, acute or chronic pusser endometritis which is most often caused by Pasteurella multocida and Escherichia coli bacterial species. Among non-reproducing females cyst in the uterus, inflammation and uterine wall lesion are common (Bensinger et al., 2000). In the examination of Nikodémusz et al., (1985) the reproductive organs of female brown hares $(n=183)$ was studied, and it was found that $39.5 \%$ of the samples had some pathological lesion. In Germany, 114 female brown hares were examined and neither the pregnancy rate $(69.8 \%)$ nor the health status and the number of fetuses $(2.02 \pm 0,1)$ indicated any impairment of reproductive fitness (Görlitz et al., 2001). The temperate oceanic climate in Belgium and the temperate continental climate in lower Austria did not significantly affect the annual reproductory performance of female brown hares (Hackländer et al., 2011)

The average weight of the testicles in December is about 10.66-12.03 $\mathrm{g}$ and in October only $2.06 \mathrm{~g}$ (Brodowski et al., 2001). In our survey at the end of November the testicles of male adult hares was significantly heavier than by juvenile ones. The older hares may earlier participate in reproduction. During the examination of the reproductive fitness of 138 male brown hares in Germany, no disturbance of spermitogenesis could be observed, although the samples came from a habitat with both high and low hare population density (Blottner et al., 2001).

Conclusions: The selected indicators may help in preplanning processes for wildlife associations. It is important to bear in mind that there can be huge differences from year to year and hunting area by hunting area but this last one in this study is not detected. Although the fertility indicators can play a key role in population dynamics of brown hare definitely not the main causes of decresing populations trend in Hungary. We assumed themortality (pre and postnatal) causes and other factors which affected the reproductive fitness (e.g weather factors, predators) must be investigated for more destination.

Acknowledgements: The publication is supported by the EFOP-3.6.3-VEKOP-16-2017-00008 project and Doctoral School of Animal Science of University of Debrecen. The project is co-financed by the European Union and the European Social Fund. We are grateful to two hunting assocations for helping to collect samples: 
Kossuth Hunting Assotiation in Túrkeve and Megyer Hunting Assotiation in Békéscsaba. We would like to thank engineers of wildlife management and professional hunters for their contributions. We express our gratitude to Tivadar Kontos, Viktor Máté (Túrkeve) and Gábor Szakál (Békéscsaba) for their help.

\section{REFERENCES}

Antoniou, A., G. Kotoulas, A. Magoulas, and P. C. Alvares (2008). Evidence of autumn reproduction in female European hares (Lepus europaeus) from southern Europe. Eur. J. Wildlife Res. 54: 581-587.

Bensinger, S., K. Kugelschafter, U. Eskens, A. Sobiraj, and G. Sobiraj (2000). Untersuchungen zur jährlichen Reproduktionsleistung von weiblichen Feldhasen (Lepus europaeus Pallas 1778) in Deutschland. Z. Jagdwiss. 46: 73-83.

Beuković, M., N. Đorđević, Z. Popovic, D. Beuković, and M. Djordjevic (2011). Nutrition specificity of brown hare (Lepus europaeus) as a cause of decreased number of population. Contemporary agriculture. 60: 403-412.

Beuković, M., D. Beuković, Z. Popovic, N. Djordjevic, and M. Djordjevic (2013). Impact of climatic factors to the percentage of young in the population of brown hare (Lepus europaeus P) in the Bačka district. Acta veterinaria. 63: 111122.

Beuković, M., I. Stanic, A. Bozic, D. Beuković, M. Djan, and N. Velickovic (2013). Correlation of hunting mass with reproductive potential of female hare (Lepus europaeus P.) Proc. 2 th. International symposium on hunting "Modern aspects of sustainable management of game population". Conference paper. University of Novi sad. 73-78.

Beuković, M., D. Beuković, V. Bursic, S. Krstović, J. Igor, and V. Lavadinovic (2017). The presence of pesticides in the fatty tissue of brown hare (Lepus europaeus Pall.): Pilot test in one hunting ground of Bačka territory. Proc. Book of Abstracta, Conference "Sustainalble Forestry: Fact or Fiction?" Conference paper. Skopje, BJR Macedonia. 37.

Beuković, D., Z. Popovic, M. Beuković, V. Bursic, N. Đorđević, S. Krstović, J. Igor, and V. Lavadinovic (2018). The pesticide in brown hare adipose tissue as consequence of anthropogenic factors. Proc. International symposium on animal science (ISAS). Faculty of Agriculture, Belgrade-Zemun, Serbia 69-74.

Blottner, S., A. Lange, F. Görlitz, M. Faßbender, A. Broich, M. Quest, M. Gilles, T. Lengwinat, and B. Hildebrandt (2001). Untersuchungen zur
Reproduktiven Fitness am lebenden männlichen Feldhasen aus unterschiedlichen Habitaten. Z. Jagdwiss. 47: 84-91.

Bray, Y., E. Marboutin, R. Peroux, and J. Ferron (2003). Reliability of stained placentalscar counts in European hares. Wildl. Soc. Bull. 31:(1) $237-$ 246.

Brodowski, A. K., K. Jewgenow, Z. Pielowski, and S. Blottner (2001). Seasonal changes in histological-morphometric parameters of testes in the European brown hare. Z. Jagdwiss. 47:(1) 26-33.

Broekhuizen, S. and F. Maaskamp (1981). Annual production of young in brown hares (Lepus europaeus) in the Netherlands. J. Zool. 193: 499-516.

Caughley, G (1977). Analysis of vertebrate populations. New Jersey, USA: Blackburn Press. 226p.

Caughley, G. and A. R. E. Sinclairs (1994). Wildlife ecology and management. Boston, USA: Blackwell Science. 334p.

Chapman, D. I (1974). Reproductive physiology in relation to deer management. Mamm Review 4 (3): 61-74. Proceedings of a Symposium on the Biological Basis of Deer Management. 4 (3):6174.

Csányi, S (ed.) (2016). National Game Management Database 1960-2016. St. Stepfen University, Institute for Wildlife Conversation. Gödöllö, Hungary.

Faragó, S (2002). Vadászati állattan. Mezőgazda Kiadó, Budapest.

Farkas, D (1983). Eltérő egyedsűrüségü mezei nyúlállományok reprodukciós képességének vizsgálata. Beszámoló a Természet és Vadvédelmi Állomás 1983. évi munkájáról. Fácánkert, 37-40.

Gál, J. and M. Marosán (2002). A méhhegek alapján történő alomszám meghatározás mezei nyúlban. Vadgazda. 1: (3) 32.

Gál, J (2006). A Lajta-Hanság mezei nyúl állományának vizsgálata különös tekintettel annak egészségügyi helyzetére. $\mathrm{PhD}$ thesis. University of West Hungary.

Görlitz, F., M. Faßbenderß, A. Broich, M. Quest, S. A. Blottner, M. Gilles, T. Lengwinat, H. Spittler, and T. B. Hildebrandt (2001). Untersuchungen zur reproduktiven Fitness lebender weiblicher Feldhasen aus unterschiedlichen Habitaten. Z Jagdwiss. 47: 92-99.

Hackländer, K., C. Zeitlhofer, T. Ceulemans, and F. Suchentrunk (2011). Continentality affects body condition and size but not yearly reproductive output in female European hares (Lepus europaeus). Mamm. Biol. 76: 662-664. 
Hansen, K (1992). Reproduction in European hare in a Danish farmland. Acta Theriol. 37: (1-2) 27-40.

Kamieniarz, R., U. Voigt, M. Panek, E. Strauss, and E. Niewęgłowski (2013). The effect of landscape structure on the distribution of brown hare Lepus europaeus in farmlands of Germany and Poland. Acta Theriol. 58: 39-46.

Kovács, Gy (1986). Methods of estimation for practicing game farmers. Estimating the stocking density of the hare with a reflector. Wildlife biology. 1: 73-79. (in Hungarian)

Kovács, Gy. and I. Heltay (1993). The rabbit. Ecology, farming, hunting. Hubertus Bt. and Hungarian Agriculture Ltd. Budapest. (in Hungarian)

Kozdrowski, R., M. Dzięcioł, E. Stańczyk, M. Ochota, P. Sławuta, and M. J. Siemieniuch (2011). Artificial induction of superfetation in the European hare (Lepus europaeus). Z. Jagdwiss. 57: 333-336.

Köhalmy, T (1999). Korbecslések. Szarvastól a siketfajdig. Nimród Vadászakadémia. Budapest, Hungary. $85-87 \mathrm{p}$.

Majzinger, I (2013). Preliminary results of reproductive parameters of the brown hare on field territories. Lucrari stiintifice Managament Agricol. 15: (1) 13-17.

Majzinger, I., and Csányi, S (2017). Útmutató az adatokon alapuló mezei nyúl-gazdálkodáshoz. Szent István Egyetemi Kiadó. Gödöllő, Hungary. 70p.

Marboutin, E., Y. Bray, R. Pèroux, B. Mauvy, and A. Lartiges (2003). Population dynamics in European hare: breeding parameters and sustainable harvest rates. J. Appl. Ecol. 40: 580591.

Martinet, L (1980). Oestrus behavior, follicular growth and ovulation during pregnancy in the hare (Lepus europaeus). J. Reprod. Fertil. 59: 441445.

Mezei, M., V. Bursic, G. Vukovic, A. Petrovic, D. Beuković, M. Dušan, and M. Beuković (2018). Pesticides and the loss of biodiversity: European hare. Proc. 26th International Conference Ecological Thruth and Enviromental Research Eco Ter University of Belgrade, Technical Faculty in Bor. 221-225 p.

Möller, D (1980). Der Verlauf der Fortpflanzungsaktivität beim Feldhasen (Lepus europaeus Pallas, 1778) im Jahresablauf. Beitr. Jagd und Wildforsch. 11:310-324.

Nikodémusz, E., G. Kovács, and F. Vetési (1985). On the pathology of the female reproductive tract in the european hare. In: Crombrugghe SA editor. Transactions of the 17 th Congress of the
International Union of Game Biologists1985; 17-21 September 1985 Brussels, BE.

Panek, M (2009). Factors Affecting Predation of Red Foxes Vulpes vulpes on Brown Hares Lepus europaeus During the Breeding Season in Poland. Wildlife Biology. 15 (3): 345-349.

Pintur, K., N. Popović, A. Alegro, K. Severin, A. Slavica, and E. Kolić (2006). Selected indicators of Brown hare (Lepus europaeus Pallas, 1778) population dynamics in northwestern Croatia. Vet. arhiv. 76:199-209.

Pielowski, Z., and M. Pinkowski (1992). A 25-year study of a hare population on the hunting grounds of the Research station at Czempin. In: Hare International Symposium. (Pielowski, Z., ed.). Polish Hunting Association. Warszawa, Poland, 150-155. p

Reynolds, J. C., C. Stoate, M. Brockless, H., N. J. Aebischer, and C. S. Tapper (2010). The consequences of predator control for brown hares (Lepus europaeus) on UK farmland. Z. Jagdwiss. 56: 541-549.

Roedenbeck, I. A., and P. Voser (2008). Effects of roads on spatial distribution abundance and mortality of brown hare (Lepus europaeus) in Switzerland. Z. Jagdwiss. 54: 425-437.

Šelmić, V (1984). Proučavanja zakonomernosti dinamike populacije zeca u Vojvodini i njihova primena $u$ planiranju racionalnog korištenja. Dizertacija. Šmarski fakultet Beograd, Srbija i Crna Gora.

Smith, R. K., NV. Jennings, and S. Harris (2005). A quantitative analysis of the abundance and demography of European hares Lepus europaeus in relation to habitat type, intensity of agriculture and climate. Mammal Review. 35: 124.

Széky, P (1973). Szaporodásbiológiai vizsgálatok a mezei nyúl (Lepus europaeus) hímjeinél. A vadgazdálkodás fejlesztése. Apróvadtenyésztés 6: 5-21.

Underwood, A. J (1996). Experiments in Ecology. University Press. Cambridge, UK.

Van Tu, P., and Sas, B (1989). A kadmium anyagforgalma és a terhelés élelmezéstoxikológiai, valamint -egészségügyi következményei. Magy Allatovosok. 44: (11) 665-668.

Vetési, F (1990). Házinyúl-egészségtan. Mezőgazdasági Kiadó. Budapest, Hungary.

Zellweger-Fischer, J., M. Kéry, and G. Pasinelli (2011). Population trends of brown hares in Switzerland: The role of land-use and ecological compensation areas. Biol. Conserv. 144:13641373 . 